\title{
PENGARUH MODEL PROBLEM BASED LEARNING TERHADAP HASIL BELAJAR SISWA PADA MATERI FLUIDA STATIS DI KELAS XI SEMESTER II SMA NEGERI 1 SELESAI T.P 2014/2015
}

\author{
Elizabeth M Marpaung dan Usler Simarmata \\ Jurusan Fisika FMIPA Universitas Negeri Medan \\ marpaungelizabeth@gmail.com
}

\begin{abstract}
ABSTRAK
Penelitian ini bertujuan untuk mengetahui pengaruh model problem based learning terhadap hasil belajar siswa pada materi pokok fluida statis. Jenis penelitian ini adalah quasi eksperimen dengan two group pre-testt-posttest design. Populasi dalam penelitian ini adalah seluruh siswa kelas XI semester II yang terdiri dari 7 kelas. Pengambilan sampel dilakukan dengan cara cluster random sampling yaitu kelas XI Ia 1 sebagai kelas eksperimen dengan jumlah siswa sebanyak 30 siswa dan kelas XI IA 2 sebagai kelas kontrol dengan jumlah siswa sebanyak 30 siswa. Instrumen yang digunakan yaitu tes hasil belajarsebanyak 15 soal dalam bentuk uraian. Teknik analisis data yang digunakan adalah uji beda (uji-t)data berdistribusi normal dan homogen. Berdasarkan analisis data dan uji hipotesis diperoleh bahwa ada pengaruh model pembelajaran problem based learning $(\mathrm{PBL})$ terhadap hasil belajar siswa pada materi pokok fluida statis.
\end{abstract}

Kata Kunci : problem based learning, hasil belajar

\section{ABSTRACT}

This study aimed to determine the effect of learning model Problem Based Learning (PBL) on learning outcomes of students in the subject matter of fluida statis. This research is a quasi experimental with two group pretest-posttest design. The population is the entire second semester of tenth grade students consisting of 7 class. Sampling was done by cluster random sampling that is class XI Ia 1 as the experimental class the number of students by 30 students and class XI Ia 2 as the control class the number of students by 30 students. The instrument used is the achievement test as many as 15 questions in the form of essay test. Data analysis technique used is test difference(test $-t$ ) the data were normally distributed and homogeneous. Based on data analysis and hypothesis testing showed that there is effect of Problem Based Learning model on learning outcomes of student in the subject matter of fluida statis.

Keywords : problem based learning, learning outcome

\section{PENDAHULUAN}

Perkembanganilmu

pengetahuan dan teknologi saat ini sangat mempengaruhi berbagai aspek kehidupan manusia. Dunia pendidikanmerupakan salah satu dari aspek tersebut.

Pendidikan adalah salah satu bentuk perwujudan kebudayaan manusia yang dinamis dan syarat perkembangan. Oleh karena itu, perubahan atau perkembangan pendidikan adalah hal yang memang seharusnya terjadi sejalan dengan perubahan budaya kehidupan (Trianto 2009: 1).

Idealnya pendidikan tidak hanya berorientasi pada masa lalu dan 
masa kini, tetapi sudah seharusnya merupakan proses yang mengantisipasi dan membicarakan masa depan. Menurut Buchori dalam Trianto (2009: 5) bahwa : "Pendidikan yang baik adalah pendidikan yang tidak hanya mempersiapkan para siswanya untuk sesuatu profesi atau jabatan, tetapi untuk menyelesaikan masalah-masalah yang dihadapinya dalam kehidupan sehari-hari". Dengan demikian, untuk memahami konsep-konsep dan memudahkan guru dalam mengajarkan konsep-konsep tersebut, diperlukan suatu pendekatan pembelajaran yang langsung mengaitkan materi konteks pelajaran dengan pengalaman nyata dalam kehidupan sehari-hari.

Berdasarkan hasil pengamatan penulis berdasarkan observasi pada tanggal 12-13 januari 2014 di SMA Negeri 1 selesai, ketika penulis penyebaran angket, kebanyakan siswa tidak menggemari pelajaran fisika. Kebanyakan siswa juga berpendapat tentang pelajaran fisika bahwa pelajaran fisika merupakan pelajaran kurang menyenangkan,sulit dan membosankan. Terlalu banyak rumus sehingga menyulitkan siswa untuk mengingat rumus-rumus tersebut. Apalagi ketika diberikan soal kebanyakan siswa tidak mengerti membaca soal dan menentukan rumus apa yang dipakai. Sehingga pada akhirnya timbul anggapan pada diri siswa bahwa mata pelajaran fisika hanya dipelajari oleh orang-orang yang ingin menjadi ilmuwan atau lebih jelasnya sebagai ahli fisika.

Selain informasi dari siswa, peneliti juga memperoleh informasi dari guru bidang studi fisikadari hasil wawancara diperoleh bahwa, diketahui bahwa nilai rata-rata ujian fisika siswa kelas XI masih rendah jika dilihat dari nilai Kriteria Ketuntasan Minimal (KKM) yaitu 75. Data ketuntasan Minimal ditunjuk pada Tabel 1.
Tabel 1. Ketuntasan Minimal (KKM)

\begin{tabular}{ccccc}
\hline Kelas & Semester & Skor & Siswa & Persentase \\
& & & & \\
\hline XI- $^{-}$ & Semester & $<75$ & 18 & 60 \\
IPA-1 & 1 & $\geq 75$ & 12 & 40 \\
& $2013 / 2014$ & & & \\
XI- $^{-}$ & Semester & $<75$ & 19 & 63,33 \\
IPA-2 & 1 & $\geq 75$ & 11 & 36,67 \\
& $2013 / 2014$ & & & \\
\hline
\end{tabular}

Berdasarkan data pada Tabel 1 menunjukkan bahwa nilai rata-rata ujian fisika kelas XI IPA SMA Negeri 1 Selesai untuk kedua Tahun Pelajaran tersebut masih tergolong rendah.

Berbagai usaha telah dilakukan guru dalam mengatasi permasalahan tersebut, seperti melakukan diskusi dan tanya jawab. Tetapi usaha itu belum mampu merangsang siswa untuk aktif dalam pembelajaran, karena siswa yang menjawab pertanyaan guru cenderung didominasi oleh beberapa orang saja. Usaha lain yang dilakukanguru adalah dengan melaksanakan pembelajaran dalam setting kelompok kecil. Akan tetapi siswa lebih banyak bekerja sendirisendiri dalam menyelesaikan soal-soal yang diberikan guru. Kenyataan ini menunjukkan bahwa usaha-usaha yang telah dilakukan guru tampaknya belum membuahkan hasil optimal dalam meningkatkan hasil belajar siswa.

Berdasarkan uraian diatas, jelaslah bahwa model dan metode mengajar mempengaruhi suasana dan hasil belajar siswa. Guru dituntut dapat memilih model pembelajaran yang dapat memacu semangat setiap siswa untuk secara aktif ikut terlibat dalam pengalaman belajarnya. Salah satu alternatif model pembelajaran yang memungkinkan dikembangkannya keterampilan berpikir siswa (penalaran, komunikasi, dan koneksi) dalam memecahkan masalah adalah problem based learning (PBL).

\begin{tabular}{lcc}
\multicolumn{1}{c}{ Menurut } & Tan & model \\
PBLmerupakan & inovasi & dalam \\
pembelajaran & karena dalam & PBL
\end{tabular}


kemampuan berpikir siswa betul-betul dioptimalisasikan melalui proses kerja kelompok atau tim yang sistematis, sehingga siswa dapat memberdayakan, mengasah, menguji, dan mengembangkan kemampuan berpikirnya secara berkesinambungan (Rusman 2012: 229).

Penerapan model PBL ini sudah pernah diteliti oleh beberapa peneliti sebelumnya, seperti Agustin Maya Pratiwi (2014) menerapkan model PBL di SMA N 7 Medan diperoleh nilai ratarata pretes kelas eksperimen 42,28 setelah diberi perlakuan dengan model PBL maka hasil belajar fisika meningkat dengan rata-rata 73 . Menurut hasil penelitian Mawardina Silalahi (2014) yang menerapkan model PBL di SMA N 1 Palipi Kecamatan Palipi Kabupaten Samosir setelah dilakukan perlakuan dengan model PBL diperoleh hasil postes 80,09. Kelemahan dari peneliti mawardina mengukur aktivitas siswa selama proses pembelajaran berlangsung. Amir Hamzah (2014) yang juga menerapkan model PBL di SMA Swasta Budi Agung Medan setelah diberikan perlakuan dengan Model PBL diperoleh hasil postes 73,6 . Berdasarkan hasil ketiga peneliti ini diketahui bahwa ada pengaruh yang signifikan antara model pembelajaran PBL terhadap hasil belajar siswa.

Berdasarkan uraian di atas adapun yang menjadi tujuan penelitian ini adalah

a. Untuk mengetahui hasil belajar fisika setelah menggunakan model $P B L$ pada materi Fluida Statis di kelas XI semester II SMA Negeri 1 Selesai T.P 2014/2015.

b. Untuk mengetahui hasil belajar fisika setelah menggunakan pembelajaran konvensional pada materi Fluida Statis di kelas XI semester II SMA Negeri 1 Selesai T.P 2014/2015.

c. Untuk mengetahui aktivitas dengan model $P B L$ pada materi Fluida Statis di kelas XI semester
II SMA Negeri 1 Selesai T.P 2014/2015.

d. Untuk mengetahui ada tidaknya pengaruh yang signifikan model pembelajaran problem based learning (PBL) terhadap hasil belajar pada materi pokok Fluida Statis kelas XISemester II SMA Negeri 1 Selesai Tahun Pelajaran $2014 / 2015$ ?

\section{METODE PENELITIAN}

Penelitian ini dilaksanakan di SMA Negeri 1Selesai dan waktu pelaksanaannya pada Tahun Pelajaran 2014/2015 Semester II.Populasi dalam penelitian ini adalah seluruh siswa kelas XI SMA Negeri 1Selesai T.P 2014/2015 berjumlah 7 kelas. Pada penelitian ini sampel terdiri dari dua kelas yang dipilih dengan teknik cluster random sampling yaitu kelas XIIA-1 sebagai kelas eksperimen yang menerapkan model pembelajaran PBL dengan jumlah siswa adalah 30 siswadan kelas XI IA-2 sebagai kelas kontrol dengan jumlah siswa sebanyak 30 siswa dengan menerapkan model pembelajaran konvensional.

Jenis penelitian yang digunakan dalam penelitian ini adalah quasi experiment.Desain penelitian yang digunakan yaitu control group pretestposttest seperti yang terlihat pada tabel 2 .

Tabel 2. Control Group Pretest Posttest

\begin{tabular}{|l|l|l|l|}
\hline Kelas & Pretes & Perlakuan & Postes \\
\hline Eksperimen & $O_{1}$ & $X_{1}$ & $O_{2}$ \\
\hline Kontrol & $O_{1}$ & $X_{2}$ & $O_{2}$ \\
\hline
\end{tabular}

Keterangan:

$O_{1}=$ pretes

$\mathrm{O}_{2}=$ postes

$X_{I}=$ model pembelajaran problem based learning

$X_{2}=$ model pembelajaran konvensional.

Instrumen yang digunakan dalam penelitian ini adalah tes hasil hasil belajarsebanyak 15 soal uraian dan 
divalidasi. Setelah divalidasi tes hasil belajar sebanyak 15 soal uraian akan diberikan pada pre-test dan post-test.

Uji validitas yang digunakan dalam penelitian ini yaitu validitas isi.

Pengujian hipotesis ada dua cara yaitu:ujituntuk mengetahui kemampuan awal siswa pada kedua kelas yaitu pada kelas eksperimen dan kelas kontrol.

\section{HASIL DAN PEMBAHASAN Hasil Penelitian}

Dibawah ini adalah tabel-tabel dari nilai rata-rata, uji normalitas, uji homogenitas dari pre-test dan post-test kedua kelas secara ringkas.

Tabel 3.Nilai Rata-Rata Hasil Belajar Pre-test danPosttes kedua

\begin{tabular}{|l|l|l|}
\multicolumn{2}{c|}{ kelas } \\
\hline \multirow{2}{*}{ Kelas } & \multicolumn{2}{c|}{ Hasil Belajar } \\
\cline { 2 - 3 } & Pre-test & Posttest \\
\hline Eksperimen & 30,5 & 88,00 \\
\hline Kontrol & 30,3 & 70,83 \\
\hline
\end{tabular}

Tabel 3 menunjukkan bahwa nilai rata-rata hasil belajar pre-test pada kedua kelas hampir sama, sedangkan setelah diberikan perlakuan diperoleh bahwa nilai rata-rata hasil belajar post test kelas eksperimen lebih tinggi dibandingkan di kelas kontrol.

Berdasarkan hasil pengujian normalitas data diperoleh normal untuk data pretes dan postes pada kedua kelas. Hasil uji normalitas data dapat dilihat dalam Tabel 4.

Tabel 4. Perhitungan Uji Normalitas Hasil Belajar Pre-test dan Post-test

\begin{tabular}{|c|c|c|c|c|c|}
\hline $\begin{array}{l}\mathrm{N} \\
\mathrm{O}\end{array}$ & Data & $\begin{array}{c}\text { Kela } \\
\text { s }\end{array}$ & Lhit & $\begin{array}{c}\begin{array}{c}\text { Ltab } \\
(\alpha= \\
0.05)\end{array}\end{array}$ & $\begin{array}{c}\text { Kete } \\
\text { rang } \\
\text { an }\end{array}$ \\
\hline \multirow[t]{2}{*}{1.} & \multirow{2}{*}{$\begin{array}{l}\text { Pret } \\
\text { es }\end{array}$} & $\begin{array}{l}\text { Eks } \\
\text { Peri } \\
\text { men }\end{array}$ & $\begin{array}{c}0,1 \\
544\end{array}$ & 0,161 & $\begin{array}{l}\text { Nor } \\
\text { mal }\end{array}$ \\
\hline & & $\begin{array}{l}\text { Kont } \\
\text { rol }\end{array}$ & $\begin{array}{c}0,1 \\
493\end{array}$ & 0,161 & $\begin{array}{l}\text { Nor } \\
\text { mal }\end{array}$ \\
\hline 2. & $\begin{array}{c}\text { Post } \\
\text { es }\end{array}$ & $\begin{array}{l}\text { Eks } \\
\text { Peri } \\
\text { men }\end{array}$ & $\begin{array}{c}0,1 \\
594\end{array}$ & 0,161 & $\begin{array}{l}\text { Nor } \\
\text { mal }\end{array}$ \\
\hline
\end{tabular}

\begin{tabular}{|l|l|l|c|c|c|}
\hline & $\begin{array}{l}\text { Kont } \\
\text { rol }\end{array}$ & $\begin{array}{c}0,1 \\
121\end{array}$ & 0,161 & $\begin{array}{l}\text { Nor } \\
\text { mal }\end{array}$ \\
\hline
\end{tabular}

Tabel 4 menunjukan bahwahasil belajar data pre-test dan data post-test berdistribusi normal.

Hal ini terlihat dari harga $\mathrm{L}_{\text {tabel }}$ melebihi Lhitung (Lhitung < L tabel) berarti data berdistribusinormal.

Berdasarkan hasil perhitungan uji kesamaan dua varians diperoleh kesimpulan bahwa data tes awal dan tes akhir kedua kelompok tersebut homogen. Hasil uji homogenitas dapat dilihat dalam Tabel 5.

Tabel 5. Perhitungan Uji Homogenitas Pre-test dan Post-test

\begin{tabular}{|c|c|c|c|c|c|c|}
\hline No & Data & Kelas & $\begin{array}{l}\text { Vari } \\
\text { ans }\end{array}$ & $\begin{array}{l}\text { F } \\
\text { hit }\end{array}$ & $\begin{array}{l}\mathrm{F}_{\mathrm{t}} \\
\mathrm{ab}\end{array}$ & $\begin{array}{c}\text { Ket } \\
\text { era } \\
\text { nga } \\
\text { n }\end{array}$ \\
\hline \multirow[t]{2}{*}{1.} & \multirow{2}{*}{$\begin{array}{c}\text { Pret } \\
\text { es }\end{array}$} & $\begin{array}{l}\text { Eks } \\
\text { perim } \\
\text { en }\end{array}$ & 64,4 & \multirow{2}{*}{$\begin{array}{l}0, \\
9 \\
1\end{array}$} & \multirow{2}{*}{$\begin{array}{l}1, \\
6 \\
5\end{array}$} & \multirow{2}{*}{$\begin{array}{l}\text { Ho } \\
\text { mo } \\
\text { gen }\end{array}$} \\
\hline & & $\begin{array}{l}\text { Kontr } \\
\text { ol }\end{array}$ & $\begin{array}{c}70,5 \\
7\end{array}$ & & & \\
\hline \multirow[t]{2}{*}{2.} & \multirow{2}{*}{$\begin{array}{c}\text { Post } \\
\text { es }\end{array}$} & $\begin{array}{l}\text { Eksp } \\
\text { erime } \\
\text { n }\end{array}$ & $\begin{array}{c}30,3 \\
4\end{array}$ & \multirow{2}{*}{$\begin{array}{l}0, \\
4 \\
2\end{array}$} & \multirow{2}{*}{$\begin{array}{l}1, \\
6 \\
5\end{array}$} & \multirow{2}{*}{$\begin{array}{l}\text { Ho } \\
\text { mo } \\
\text { gen }\end{array}$} \\
\hline & & $\begin{array}{l}\text { Kontr } \\
\text { ol }\end{array}$ & $\begin{array}{c}72,5 \\
5\end{array}$ & & & \\
\hline
\end{tabular}

Berdasarkan Tabel 5 diketahui bahwa sampel yang berupa kelas eksperimen dan kelas kontrol berasal dari populasi yang homogen.

Hal ini terlihat dari harga $\mathrm{F}_{\text {hitung }}$ tidak melebihi $\mathrm{F}_{\text {tabel }} \quad\left(\mathrm{F}_{\text {hitung }}<\mathrm{F}_{\text {tabel }}\right)$ yang mengindikasikan bahwa sampel berasal dari populasi yang homogen.

Setelah data memenuhi persyaratan homogenitas dan normalitas maka pengujian hipotesis dalam penelitian ini menggunakan uji beda (uji t) dapat dilihat pada Tabel 6 . 
Tabel 6. Perhitungan Uji Hipotesis

\begin{tabular}{|c|c|c|c|c|c|c|}
\hline $\begin{array}{l}\mathrm{N} \\
\mathrm{O}\end{array}$ & Data & Kelas & $\begin{array}{c}\text { Rat } \\
\mathrm{a}^{-} \\
\text {Rat } \\
\mathrm{a}\end{array}$ & $t_{\text {hit }}$ & $t_{t a b}$ & $\begin{array}{c}\text { Kesi } \\
\text { mpul } \\
\text { an }\end{array}$ \\
\hline \multirow[b]{2}{*}{1.} & \multirow[b]{2}{*}{$\begin{array}{c}\text { Pret } \\
\text { es }\end{array}$} & $\begin{array}{l}\text { Ekspe } \\
\text { rimen }\end{array}$ & $\begin{array}{c}30 \\
5\end{array}$ & \multirow[b]{2}{*}{$\begin{array}{c}0,0 \\
93\end{array}$} & \multirow[b]{2}{*}{$\begin{array}{c}2,0 \\
02\end{array}$} & \multirow{2}{*}{$\begin{array}{c}\text { Kem } \\
\text { amp } \\
\text { uan } \\
\text { awal } \\
\text { sisw } \\
\text { a } \\
\text { sama }\end{array}$} \\
\hline & & $\begin{array}{l}\text { Kontr } \\
\text { ol }\end{array}$ & $\begin{array}{c}30, \\
3\end{array}$ & & & \\
\hline \multirow[b]{2}{*}{2.} & \multirow[b]{2}{*}{$\begin{array}{c}\text { Post } \\
\text { es }\end{array}$} & $\begin{array}{l}\text { Ekspe } \\
\text { rimen }\end{array}$ & $\begin{array}{c}88, \\
00 \\
\end{array}$ & \multirow[b]{2}{*}{$\begin{array}{c}9,2 \\
3\end{array}$} & \multirow[b]{2}{*}{$\begin{array}{c}1,6 \\
7\end{array}$} & \multirow{2}{*}{$\begin{array}{c}\text { Ada } \\
\text { peng } \\
\text { aruh } \\
\text { mode } \\
\text { l } \\
\text { pem } \\
\text { belaj } \\
\text { aran } \\
\text { PBL }\end{array}$} \\
\hline & & $\begin{array}{l}\text { Kontr } \\
\text { ol }\end{array}$ & $\begin{array}{l}70 \\
83\end{array}$ & & & \\
\hline
\end{tabular}

Berdasarkan Tabel 6 hasil uji Lillifors dengan menggunakan data pre-test diperoleh harga $t_{\text {hitung }}<t_{\text {tabel }}$ berarti $\mathrm{H}_{\mathrm{o}}$ diterima yaitu kemampuan awal siswa pada kelas eksperimen sama dengan kemampuan awal siswa pada kelas kontrol. Untuk uji Lillifors yang menggunakan data post-test diperoleh bahwa $t_{\text {hitung }}>t_{\text {tabel. }}$. Dapat diambil kesimpulan bahwa hipotesis $\mathrm{H}_{\mathrm{a}}$ diterima yaitu ada pengaruh model pembelajaran PBLterhadap hasil belajar siswa dan siswa pada materi pokok fluida statis di kelas XI semester II di SMA Negeri 1 Selesai T.P. 2014/2015.

\section{Pembahasan}

Berdasarkan hasil penelitian diperoleh bahwa data pretes hasil belajar siswa yang ditunjukkan pada tabel 1 masih berada di bawah KKM hal ini menunjukkan bahwa dari 30 jumlah siswa yang mengikut pretes pada masing-masing kelas sampel hasil belajar satu siswa pun tidak ada yang mencapai nilai 75. Hal ini menunjukkan bahwa siswa tidak sepenuhnya mempelajari materi yang akan diajarkan untuk pertemuan selanjutnya. Hasil analisis data peneliian dari data pretes kedua kelas sampel menunjukkan bahwa data yang diperoleh terdistribusi secara normal dan sampel berasal dari populasi yang homogen. Setelah data tersebut normal dan homogen, data kemudian dilanjutkan dengan melakukan uji hipotesis kemampuan awal dari kedua ruang sampel.

Hasil menunjukkan hipotesis kemampuan awal pada kelas eksperimen dan kelas kontrol adalah sama, hal ini berarti kesadaran siswa untuk belajar di rumah sebelum mempelajari di sekolah masih sangat rendah. Akan tetapi setelah peneliti memberikan perlakuan kepada kedua kelas yaitu kelas eksperimen dengan model pembelajaran problem based learning dan kelas kontrol dengan model pembelajaran konvensional diperoleh peningkatan hasil belajar, terlihat dari tabel 4.1 diperoleh nilai rata-rata pretes pada kelas eksperimen30,5 dan simpangan baku 8,03. Pada kelas kontrol diperoleh nilai rata-rata 30,3 dan simpangan baku 8,4. Sesuai dengan uji normalitas (tabel 4) dan uji homogenitas (tabel 5) diperoleh bahwa sampel berasal dari populasi yang berdistribusi normal dan homogen. Dengan perhitungan uji $t$ pada tabel 4.5 diperoleh nilai pretes $t_{\text {hitung }}<t_{\text {tabel }}$ yaitu $0,093<2,002$ maka Ho diterima, dengan kata lain kemampuan awal siswa kelas eksperimen sama dengan kemampuan awal siswa kelas kontrol. Untuk nilai rata-rata postes kelas eksperimen diperoleh 88,00 dengan simpangan baku 5,51 sedangkan pada kelas kontrol diperoleh nilai rata-rata 70,83 dengan simpangan baku 8,52. Setelah diuji dengan uji t diperoleh $t_{\text {hitung }}>t_{\text {tabel }}$ yaitu 9,23>1,671 artinya Ho ditolak dan Ha diterima maka nilai hasil belajar siswa kelas eksperimen lebih besar dari pada kelas kontrol yang artinya ada pengaruh model pembelajaran PBL terhadap hasil belajar siswa pada pokok bahasan Fluida Statis di kelas SMA Negeri 1Selesai Tahun pelajaran 2014/2015.

Hasil kemampuan akhir siswa yang berujuk pada tabel 3menunjukkan 
bahwa ada peningkatan hasil belajar siswa setelah diberi perlakuan. Perbedaan hasil belajar yang diperoleh dari kelas eksperimen dan kelas kontrol tersebut karena pada kelas eksperimen yang diberi pengajaran dengan menggunakan model problem based learning yang berguna memunculkan keterampilan mengatasi masalah dan keterampilan untuk belajar secara mandiri.

Berdasarkan hasil observasi keterampilan yang diperoleh rata-rata nilai keterampilan dari siswa di kelas eksperimen nilai rata-rata pada pertemuan I sebesar 69,77, pada pertemuan II sebesar 79,58, dan pada pertemuan III sebesar 97,96 sehingga diperoleh rata-rata dari ketiga pertemuan sebesar 74,93. Adapun penilaian sikap pada pertemuan I,II, dan III yang diperoleh rata-rata nilai sikap dari siswa di kelas eksperimen 60,56 sedangkan untuk kelas kontrol diperoleh rata-rata nilai sikap pada pertemuan I,II, dan III sebesar 54,75. Dari hasil perolehan nilai sikap kedua kelas dapat dilihat bahwa nilai sikap dari kelas eksperimen lebih tinggi dibandingkan kelas kontrol. Yang mempengaruhi nilai dari kedua kelas ini terletak pada penilaian sikap ada indikator pengorganisasian, pemberian respon dan penerimaan. Pada kelas eksperimen siswa lebih aktif dibandingkan dengan siswa kelas kontrol sehingga tingkat pengorganisasiannya ketika dibentuk kelompok lebih tereksplor dbandingkan dengan kelas kontrol.

Peningkataan hasil belajar menggunakan model pembelajaran problem based learning lebih baik dikarenakan model pembelajaran ini memiliki beberapa kelebihan yaitu : 1) Menekankan kepada pengembangan aspek kognitif, afektif, dan psikomotor secara seimbang, sehingga pembelajaarn melalui model ini dianggap lebih bermakna. 2) Memberikan ruang kepada siswa untuk belajar sesuai dengan pembelajaarn mereka. 3) Merupakan model yang dianggap sesuai dengan perkembangan psikologi belajar modern yang menganggap belajar adalah proses perubahan tingkah laku berkat adaanya pengalaman dalam kehidupan sehari - hari. 4) dapat melayani kebutuhan siswa yang memiliki kemampuan di atas rata - rata. Artinya, siswa yang memiliki kemampuan belajar bagus tidak akan terhambat oleh siswa yang lemah dalam belajar.

Model PBL memiliki 5 sintaks yang dilakukan peneliti selama melakukan penelitian di SMA Negeri 1 Selesai. Pada tahap pertama (orientasi siswa pada masalah), peneliti memotivasi siwa dengan memberikan tujuan pembelajaran yang akan dicapai oleh siswa dan tahap ini peneliti memberikan masalah kepada siswa dengan memberikan pertanyaan sederhana yang berbeda didalam kehidupan sehari - hari siswa. Pada tahap kedua (mengorganisasi siswa untuk belajar), peneliti membentuk kelompok belajar yang heterogen dan membagikan LKS. Pada tahap ketiga (penyelidikan individual maupun kelompok), peneliti membimbing setiap siswa untuk mengumpulkan informasi melalui eksperimen untuk memecahkan masalah, dan melakukan diskusi kelompok sekali lagi. Pada tahap keempat (mengembangkan dan menyajikan hasil karya), peneliti membantu setiap kelompok menyelesaikan laporan hasil eksperimen. Pada tahap kelima (menganalisis dan mengevaluasi proses mengatasi masalah), peneliti membantu siswa dalam mengkaji ulang pemecahan masalah sesuai dengan tujuan pembelajaran dan materi pembelajaran.

Model pembelajaran $P B L$ tidak hanya berpengaruh terhadap hasil belajar tetapi juga dapat meningkatkan aktivitas belajar siswa.Berdasarkan observasi aktivitas siswa oleh observer, terlihat bahwa keaktifan siswa 
mempengaruhi test hasil belajar siswa. Semakin aktif siswa, semakin tinggi hasil belajar siswa dan sebaliknya. Sesuai dengan data pada tabel 4.6, 4.7, dan 4.8 , untuk kelas eksperimen pada pertemuan I diperoleh nilai rata-rata 14,17 , pertemuan II 15,23 , pertemuan III 16,63 dan nilai rata-rata akhir 73,06. Sedangkan pada kelas kontrol, nilai rata-rata pertemuan I 13,10 , nilai rata-rata pertemuan II 14,53 , nilai ratarata pertemuan III 14,53 dan nilai ratarata akhir 66,92. Dari data tersebut diketahui bahwa untuk kelas eksperimen dari pertemuan I sampai pertemuan III aktivitas belajar dengan menggunakan model pembelajaran PBL mengalami peningkatan, yaitu sebesar 9,17\%. Dalam hal ini aktivitas siswa memiliki pengaruh yang positif terhadap hasil belajar.

Berdasarkan tes hasil belajar siswa (postest), soal yang paling sering tidak terselesaikan secara sempurna oleh siswa adalah item soal nomor 4 . Penyebab hal demikian adalah penyelesaian soal yang terlalu panjang sehingga sebagian siswa malas untuk menyelesaikannya dan sebagian lagi kurang paham sampai dimana penyelesaiannya. Peneliti juga tidak melakukan uji coba instrumen soal ke sekolah lain sebelum diteliti ke sekolah SMA Negeri 1 Selesai di karenakan keterbatasan waktu sehingga peneliti tidak mengetahui kemampuan tes tersebut untuk meramalkan prestasi yang akan dicapainya, karna hanya menggunakan uji validitas isi dimana instrumen soal di validkan oleh 2 dosen fisika UNIMED.

Sesuai dengan data pada tabel 4.9 menunjukkan bahwa persentase nilai LKS tiap pertemuan mengalami peningkatan. Persentase skor kelompok siswa pada LKS I sebesar 52,6\% , pada LKS II sebesar $76 \%$ dan pada LKS III sebesar 82,6\%. Hal ini menunjukkan bahwa siswa semakin memahami tugasdan tanggung jawab mereka dalam pembelajaran pada tiap pertemuan. Kendala yang dialami peneliti dalam melakukan percobaan yaitu peneliti tidak melakukan ke empat percobaan, peneliti hanya dapat melaksanakan percobaan 1 , percobaan 2, dan percobaan 3. Hal ini dikarenakan keterbatasan waktu yang dipunyai peneliti.Bagi peneliti selanjutnya diharapkan lebih mengoptimalkan waktu dengan percobaan yang akan dilakukan, dan memilih percobaan yang lebih mengemat waktu.

Selama pelaksanaan penelitian diperoleh bahwa model pembelajaran problem based learning dapat meningkatkatkan hasil belajar siswa. Hal ini didukung dengan pernyataan dari Mutoharoh (2011) dengan judul "Pengaruh model pembelajaran berdasarkan masalah problem based learning terhadap hasil belajar fisika siswa menyimpulkan bahwa model pembelajaran berdasarkan masalah (problem based learning) mempunyai perbedaan yang berarti terhadap peningkatan hasil belajar fisika siswa pada konsep kalor. Selanjutnya Prasetio, Ngurah dan Duwi., (2014) dengan judul "Penerapan model pembelajaran problem based learning pokok bahasan kalor untuk meningkatkan hasil belajar siiswa kelas X SMA N 11 Semarang menyimpulkan bahwa hasil belajar siswa dengan menerapkan model pembelajaran problem based learning dapat meningkatkan hasil belajar. Sulaiman (2010) menyatakan bahwa siswa memperoleh manfaat dari PBL yaitu kemampulan komunikasi mereka ditingkatkan, pengetahuan mampu mereka bagikan bersama, itu mampu membantu untuk mengerti konsep dalam fisika modern. Selcuk dan Caliskan., (2010) menyimpulkan bahwa model $P B L$ lebih efektif daripada model tradisional dalam meningkatkan hasil belajar siswa.

Ada beberapa kendala yang peneliti alami seperti; (1) Jika jumlah siswa banyak, sebaiknya menggunakan media interaktif untuk melakukan penelitian, sehingga maksimal dalam 
melakukan penyelidikan melalui eksperimen sehingga kelas lebih kondusif; (2)Mengatur penggunaan waktu dengan baik, sehingga semua sintaks dalam PBL dapat terlaksana dengan baik, serta lebih mengoptimalkan pengelolaan kelas khususnya pada saat diskusi berlangsung agartidak terjadi kegaduhan-kegaduhan di dalam kelas; (3) kepada peneliti selanjutnya yang ingin meneliti tentang modelpembelajaran PBL karena aktivitas yang akan diobservasi banyak maka supaya efektif diperlukan satu observer setiap kelompok; 4) dan kepada peneliti selanjutnya sebelum melakukan penelitian diharapkan untuk mengujicobakan instrumen soal ke seolah lain terlebih dahulu agar peneliti mengetahui kemampuan tes tersebut untuk meramalkan prestasi yang akan dicapainya; 5) Tidak adanya prasarana (laboratorium) di sekolah sehingga melakukan eksperimen di dalam kelas yang membuat kelas menjadi kotor dan tidak nyaman untuk pelajaran selanjutnya, dan tidak adanya penyediaan alat dan bahan praktikum, sehingga peneliti mengeluarkan biaya yang berlebih untuk menyediakanalat dan bahan praktikum sewaktu penelitian.

\section{DAFTAR PUSTAKA}

Hamzah, A.2014.Pengaruh model pembelajaranberdasarkanmasal ah (problem basedlearning) terhadap hasil belajar belajar siswa pada materi pokok besaran dan satuan di kelas X semester 1 SMA swasta Budi Agung Medan T.P.2014/2015.Skripsi. Medan: FMIPA Unimed

Mutoharoh.,(2010). Pengaruh

Model Pembelajaran berdasarkan masalah (Problem Based Learning) terhadap hasil belajar fisika siswa, FMIPA Universitas Islam Negeri Syarif Hidayatullah, Jakarta

Prasetio,dkk. 2014. Penerapan Model Pembelajaran Problem Based Learning pokok bahasan Kalor untuk meningkatan hasil belajar siswa kelas X SMA N 11 Semarang. Universitas PGRI Semarang, Semarang

Pratiwi, A. M.2014. Pengaruh model pembelajaran berdasarkan masalah (problem based learning) terhadap hasil belajar belajar siswa pada materi pokok suhu dan kalor pada kelas X SMA Negeri 7 Medan T.P.2013/2014. Skripsi. Medan: FMIPA Unimed

Rusman. 2012.Model-model

PembelajaranMengembangkan

ProfesionalismeGuru Edisi Kedua, PT RajaGrafindo Persada

Selcuk, G dan Caliskan, S. 2010. A small scale study comparing the impacts of problem-based learning and traditional methods on student satisfaction in the introductory physics course. Procedia Social and Behavioral Sciences. Turkey

Silalahi, M.2014. Pengaruh model problem based learning (PBL)terhadap hasilbelajar siswa pada materi pokok besaran dan satuan di kelas $\mathrm{X}$ semester swastaNuhhamadiyah 8 Kisaran T.P. 2014/2015. Skripsi. Medan: FMIPA Unimed

Sulaiman, F. 2010. Students' Perceptions of Implementing Problem Based Learning in a Physics Course, Procedia Social and Behavior Sciences, New Zealand

Trianto. 2009. Mendesain Model Pembelajaran Inovatif Progresif, Kencana, Jakarta 